\section{Incidence Of Urinary Retention In A Tertiary Post Operative Hospital}

\section{Abstract}

Patients in the immediate post-operative period have several clinical features and when they are admitted in the post-anesthetic recovery room the signs and symptoms that affect the patient physically and psychologically resulting of surgical procedures begin to emerge. Urinary retention occurs frequently in these patients, as some anesthetics contribute to the development of this clinical condition. This research aims to analyze the incidence of urinary retention after surgery of patients of various specialties, correlating the type of anesthesia and the need for urinary catheterization. This study is characterized as exploratory, descriptive, with quantitative approach and was performed in a hospital of high complexity in Juazeiro do Norte. The sample was composed of the patients admitted to the post-anesthetic recovery room and during that time they presented urinary retention. Data analysis was demonstrated by the tables relating to the literature. The study contributed to the growth of scientific knowledge for hospital staff under study, as there were a large number of species records about urinary retention of patients undergoing surgical procedures that were admitted to the patient unit, especially in surgical units. That worried the nursing staff on the efficiency of systematization so there was an improvement in the quality of care, as many times, such deductions were accompanied by distension and suprapubic pain. Through these results, we could identify some interventions that have contributed to solve this nursing diagnosis, involving the whole multidisciplinary team and ensure the patient unit staff understood holistically the issues involved in this clinical condition and to be more involved in this process.
Gylmara Bezerra de Menezes Silveira1,

Hermes Melo Teixeira Batista², Gylsara Bezerra de Menezes Silveira ${ }^{3}$, Italla Maria Pinheiro Bezerra², Vitor Engracia Valenti ${ }^{4}$, Luiz Carlos de Abreu²

1 Nurse at the Cariri Regional Hospital. Rua Catulo da Paixão Cearense, S/N. Juazeiro do Norte, CE, Brazil.

2 Laboratory Design and Scientific Writing. Department of Basic Sciences, ABC Faculty of Medicine. Av Prince of Wales, 821, 821, 09060-650. Santo André, SP, Brazil.

3 Nursing Student.

4 Department of Speech and Hearing Pathology at FFC-UNESP/Marília. São Paulo. Brazil.

\section{Contact information:}

\section{Hermes Melo Teixeira Batista.}

झ hermesmelo@oi.com.br

\title{
Keywords
}

Urinary retention, impact, nursing 


\section{Introduction}

There are several discussions about urinary retention in the immediate post- operative period in the sense of understanding its relation to the type of anesthesia used in surgery, the cynical condition of the patient and the standardization of urinary catheterization. However, studies show that the main cause of urinary retention after surgery is related to the use of some painkillers, type of surgery and intravenous therapy [1].

Morphine is an analgesic widely used because it is a potent agonist of receivers mu, kappa and delta, has no ceiling effect and its cost is low. Over usage with time decreases their effectiveness and the need to increase the dose to get the previous analgesic effect. It has some side effects, notably: nausea, vomiting, pruritus, urinary retention and respiratory depression [2].

As a result of sympathetic hyperactivity there is an inhibition of the urinary tract resulting in hypomotility urethral and of the bladder and increased urinary sphincter tone, compromising the patient's urination [2].

Urinary retention, bladder emptying failure with volume exceeding $600 \mathrm{~mL}$, may be associated with severe pain. There are several recommendations in this case: palpate suprapubic region detecting bladder distention, evaluate discomfort and pain caused by retention and perform bladder catheterization relief if necessary. In the post-anesthetic recovery room after the evaluation of nursing spontaneous urination should be encouraged, informing the anesthesiologist when unsuccessful and perform urinary catheterization when prescribed [3]. It is noteworthy that this adverse event is associated with bladder distention, with risk of permanent injury of the detrusor muscle, especially in the elderly [4].

Considering the inevitable use of anesthetics in surgical procedures and its relationship to urinary retention, it is believed in the importance of understanding this relationship so that care protocols can be planned in order to minimize and / or reduce such deductions, to promote better assistance and promote the well - being of the patient [5].

The patient who undergoes surgery develops symptoms characteristic related to surgical anesthetic procedures and these features can be related to many different factors. This consideration leads to the following questions: What is the anesthesia and the anesthetic used in patients who had urinary retention? How soon after surgery the patient required the completion of urinary catheterization by the presence of these symptoms?

The patient felt pain related to urinary retention? What is the best approach and strategies to be used by the team on preventive care and curative, at the best possible time for the patient [6]?

To analyze the incidence of urinary retention in postoperative patients is of utmost importance for the daily work of the multidisciplinary team of the operating room, as through this study will be identified the relationship between various factors and thereby the assistance systematization will turn more embracing, contributing to the quality of care to the patient [7].

The surgical patient needs to be seen in a holistic way to quality care and at the research site there are difficulties about this care, related to urinary retention, requiring development of institutional protocol running since its admission to the operating room discharge, to reduce iatrogenic issues related to this symptom [8].

Thus, this research aims to analyze the incidence of urinary retention in post- operative patients of various specialties, correlating the type of anesthesia and the need for urinary catheterization.

\section{Method}

This is a prospective cohort study, whose objective was to evaluate the incidence of urinary retention in the Post-Anesthetic Care Unit of a tertiary hospital and correlate this incident to the type of anesthesia administered [9-11]. 
Study was done in Juazeiro do Norte, CE, Brazil, in a hospital of high complexity, which covers several surgical specialties, highlighting: general, orthopedic, vascular, plastic and others.

The care surgery service is performed in three ways: patients admitted to the clinic, via central regulation, coming from the hospital wards and emergency patients.

For sample identification, we evaluated the medical records of patients admitted to the surgical center from February and March 2014, after the release from the Ethics Committee. Data were collected through a structured questionnaire applied in the post- anesthetic care unit (PACU) and recorded in a specific worksheet.

The study sample consisted of patients admitted to the post-anesthetic care unit during their period of stay in the PACU who had urinary retention. Inclusion criteria were patients who had no kidney problems or other causes that could lead to the development of retention.

The study took the patient's gender approach, postoperative time that emerged urinary retention, type of anesthesia, use of opioids and present symptoms during service in the post anesthesia recovery room, answering the data collection instrument. The organization of data was performed by building tables via Excel and analyzing data by literature.

All ethical principles were respected, according to Resolution $466 / 12$ of MS, as well as respecting the confidentiality of the identity of the participants. All data were collected only by the researcher in order to have uniformity of this collection, after patient 凶s signature of the Informed Consent Statement. This study was submitted to the Platform in Brazil 02/04/2014 and approved by the Research Ethics Committee of the University Center São Camilo - UNISC with CAAE No: 27037914.3.0000.0062.

\section{Results}

The sample consisted of 838 patients who were admitted to the PACU in February and March. Out of these, 335 patients received spinal anesthesia, 387 general anesthesia and 116 underwent plexus blockage. 15 patients evolved with urinary retention in the immediate postoperative period, all of which had received spinal anesthesia (Table 1). Eleven patients were male, 14 men and 1 woman. The average age was 36.87 years, with the highest incidence in the age group between 40 to 50 years.

The results were presented in form of tables to a better understanding and analysis of data.

\section{Description of the subject}

Table 1. Characterization of the subject

\begin{tabular}{|c|c|c|c|}
\hline Subject & Gender & Age & Anesthesia \\
\hline A & Male & 24 & spinal anesthesia \\
\hline B & Male & 33 & spinal anesthesia \\
\hline C & Male & 46 & spinal anesthesia \\
\hline D & Male & 29 & spinal anesthesia \\
\hline E & Male & 55 & spinal anesthesia \\
\hline F & Male & 49 & spinal anesthesia \\
\hline G & Female & 39 & spinal anesthesia \\
\hline H & Male & 41 & spinal anesthesia \\
\hline I & Male & 22 & spinal anesthesia \\
\hline J & Male & 37 & spinal anesthesia \\
\hline K & Male & 34 & spinal anesthesia \\
\hline L & Male & 40 & spinal anesthesia \\
\hline M & Male & 28 & spinal anesthesia \\
\hline N & Male & 41 & spinal anesthesia \\
\hline O & Male & 35 & spinal anesthesia \\
\hline & & & \\
\hline
\end{tabular}




\section{Discussion}

Approximately $4 \%$ of those surveyed, 15 patients who underwent spinal anesthesia had urinary retention. It is noteworthy that patients undergoing general anesthesia or blockage of the upper limbs showed no such symptoms (Table 2).

Table 2. Type of anesthetic and urinary retention.

\begin{tabular}{|c|c|c|c|}
$\begin{array}{c}\text { Type of } \\
\text { anesthetic }\end{array}$ & $\begin{array}{c}\text { Quantity of } \\
\text { anesthetic }\end{array}$ & Urinary retention & $\%$ \\
\hline Spinal anesthesia & 335 & 15 & 4 \\
\hline General & 387 & 0 & 0 \\
\hline \multicolumn{3}{r}{ Source: data collection, 2014. } \\
\hline
\end{tabular}

Making a comparison with a other study [5], which identified the highest incidence of retention in men, $69 \%$ of the patients with urinary retention, were male. The type of anesthesia used more frequently, in which the patient developed urinary retention, in this same study was combined of general and epidural anesthesia (75\% of patients presented symptoms) [12].

The research presented, in the study period, $100 \%$ of post-operative urinary retention was drained by urinary catheter. It is noteworthy to mention that the institution does not have standard operating procedure (SOP) institutionalized for this type of procedure, and the multidisciplinary team was already concerned with the increased risk of infection due to indwelling catheterization facility. During the stay of patients in the post-anesthetic recovery room unit the costumers presented a need for urine drainage, for lack of spontaneous urination, only once [13].

The institution did not have regulated rules for this procedure; it was through this research that was developed an SOP about urinary retention and the passage of urinary catheterization, improving the quality of care and interaction of processes in the operating rooms and surgical units [13].

In a study about the urinary retention of 128 patients, 62\% underwent intermittent catheterization, $20 \%$ indwelling catheterization and $18 \%$ started with intermittent catheterization and soon after it was inserted a indwelling catheter. Out of the 102 patients who had intermittent catheterization, $69 \%$ required only one catheterization before spontaneous urination, $21 \%$ had two catheterizations, $8 \%$ were three and $2 \%$ held four catheterizations [5].

In the survey, it was identified that there were some signs and symptoms that were most prevalent presented by patients[6]. After analyzing this data it can be seen that the suprapubic pain was the most frequent, solely or combined with bladder distension (Table 3).

Table 3. signs/symptoms presented in the identification of urinary retention

\begin{tabular}{|c|c|c|}
\hline Symptoms & Quantity & Percentage \\
\hline Bladder distention & 6 & $40 \%$ \\
\hline $\begin{array}{c}\text { Suprapubic pain } \\
\text { Bladder distention / } \\
\text { suprapubic pain }\end{array}$ & 2 & $13,33 \%$ \\
\hline Total & 15 & $46,67 \%$ \\
\hline \multicolumn{2}{|c|}{ Source: data collection, 2014. } \\
\hline
\end{tabular}

In the researched institution it was identified that there was a weak point in the nursing process on this theme, since in most cases the patient had to present the suprapubic pain to identify the diagnosis and subsequent intervention.

The study contributed to the understanding of the multidisciplinary team on the strengthening of the nursing process and planning of care, with the establishment of therapeutic guidelines to improve the quality of care. 
Table 4. Signs/symptoms related to the quantity of urine and time to present symptoms

\begin{tabular}{|c|c|c|}
\hline Signs and symptoms & $\begin{array}{l}\text { Quantity in } \\
\mathrm{ml}\end{array}$ & $\begin{array}{l}\text { Post-operative in } \\
\text { hours(time) }\end{array}$ \\
\hline $\begin{array}{l}\text { Bladder distention / } \\
\text { suprapubic pain }\end{array}$ & 1200 & 06 \\
\hline Bladder distention & 720 & 19 \\
\hline Bladder distention & 200 & 09 \\
\hline Suprapubic pain & 300 & 09 \\
\hline Suprapubic pain & 400 & $08: 29$ \\
\hline Bladder distention & 500 & 05 \\
\hline $\begin{array}{l}\text { Bladder distention / } \\
\text { suprapubic pain }\end{array}$ & 300 & 09 \\
\hline $\begin{array}{l}\text { Bladder distention / } \\
\text { suprapubic pain }\end{array}$ & 700 & 10 \\
\hline Bladder distention & 600 & $10: 44$ \\
\hline Bladder distention & 1000 & 13 \\
\hline $\begin{array}{l}\text { Bladder distention / } \\
\text { suprapubic pain }\end{array}$ & 450 & 10 \\
\hline Bladder distention & 600 & $08: 42$ \\
\hline $\begin{array}{l}\text { Bladder distention / } \\
\text { suprapubic pain }\end{array}$ & 600 & 14 \\
\hline $\begin{array}{l}\text { Bladder distention / } \\
\text { suprapubic pain }\end{array}$ & 1000 & 06 \\
\hline $\begin{array}{l}\text { Bladder distention / } \\
\text { suprapubic pain }\end{array}$ & 450 & 11 \\
\hline
\end{tabular}

Note that the symptom of suprapubic pain was not related to the amount of urine drained by urinary catheterization, due to the analgesia still presented by the patient, since the survey found patients with $300 \mathrm{ml}$ of urine drained that had suprapubic pain and patients with $720 \mathrm{ml}$ with only abdominal bloating and no symptoms present.

In order to improve the interaction processes between the sectors of the operating rooms and hospitalization wards, with the main objective to pursue a better quality of care to the patient of the institution involved in the research, a questionnaire was conducted about the importance of standardizing a post-operative time to pass catheteriza- tion, so that the patient will not need to present symptoms inherent to the clinical situation he will present postoperatively.

It was through this concern that emerged the great need to deepen this research for better analysis of the feasibility of standardization of that time.

It was observed that the identification of the post-operative time for urine retention is extremely difficult to standardize, since it depends on the type of anesthesia, amount of anesthetic used, the patient's symptoms, and the amount of solution administered, etc [14].

In search of a better service to patients in the surgical wards with a better quality care, the team conducted a new process of interaction, strengthening that is almost impossible to standardize the post-operative period of time to perform the catheterization, but standardization of time to start non-invasive procedures is to be performed by the nursing team in the search for early identification of this diagnosis and interventions to be carried out with a focus on prevention [15].

It was through this research that it was identified that the highest incidence of urinary retention in surgical patients of the research institution, were at patients with blockages especially those involved with spinal anesthesia. It was observed that the bladder catheterization most used in research, almost the only, was intermittent, which according to the literature surveyed is the safest [3].

Through these results, we can identify some interventions that contributed to solve this nursing diagnosis, involving the whole multidisciplinary team and making the hospitalization ward staff understand holistically the issues involved in this clinical condition and to be more involved in this process.

As a result of the short time a patient stays in the operating room, there was the inclusion of only one intermittent bladder catheter before spontaneous urination in patients surveyed. After 
inserting the relief catheter the patient had spontaneous urination, without need for a new intervention, or had been referred to the hospitalization ward and we were not passed information about this new need for catheterization [4].

It is noteworthy to mention that after the beginning of this research, the occurrence records for lack of bladder catheterization with urinary retention in patients with bloating and / or suprapubic pain decreased almost entirely, since there was the standardization of time for the start of non-invasive procedures for encouragement of spontaneous urination, starting the nursing process with a focus on prevention and not just the treatment.

The research was conducted in a referral hospital at Juazeiro do Norte-CE, with patients undergoing surgical procedures that showed urinary retention. The interest in this research, came up the amount of incidents that were being reported (occurrence records) by the team of surgical units, about urinary retention in the immediate post-operative period, with bladder distention and suprapubic pain after discharge from the PACU.

The study contributed to the growth of scientific knowledge for the hospital staff performing the study, as there was a large number of occurrence records of urinary retention of patients undergoing surgical procedures that were admitted to the hospitalization ward, especially in surgical units. That worried the nursing staff on the efficiency of systematization, so that there was an improvement in the quality of care, as many times, such deductions were accompanied by distension and suprapubic pain.

It was observed that, especially patients undergoing spinal anesthesia, have a high risk of presentation of these symptoms and the systematization of surgical nursing care in the institution involved in the research should be strengthened, since it became clear that the team was only warned after onset of symptoms. It was through this research that has emerged the biggest concern in the early identifi- cation of risks inherent to the surgery and planning the care in relation to these risks[14].

It was also identified a difference in the incidence of urinary retention related to the gender of the patient, as there was only one female patient presented with urinary retention.

\section{Conclusion}

It was observed that, especially patients undergoing spinal anesthesia, have a high risk of presentation of these symptoms and the incidence of urinary retention related to the gender of the male. 


\section{References}

1. Tammela T, Konturri M, Lukkarinem O. Postoperative urinary retention: Incidence and predisposing factors. Scand J Urol Nephrol 1986; 20(3): 197-201.

2. Bonfim IM \& Malagutti W. Enfermagem em centro cirúrgico: atualidades e perspectivas no ambiente cirúrgico - São Paulo: Martinari, 2009.

3. Britton PM, Wright ES. Nursing care of catheterised patients. Professional nurse 2001; 5(5): 231-4

4. Keitha $H$, Diouf $E$, Tubach $F$ et al. - Predictive factors of early postoperative urinary retention in the postanesthesia care unit. Anesth Analg, 2005; 101: 592-596.

5. Fernandez, Maria do Carmo Barretto de Carvalho; Costa, Verônica Vieira da; Saraiva, Renato Ângelo. Retenção urinária pós-operatória: avaliação de pacientes em uso de analgesia com opióides. Rev. Latino-Am. Enfermagem, Ribeirão Preto, v. 15, n. 2, Apr. 2007. Disponível em: <http://www.scielo.br/scielo. php?script=sci_arttext\&pid=S0104- 11692007000200019\&ln g=en\&nrm=iso >. Acesso em 13 de Abril 2014. http://dx.doi. org/10.1590/S0104-11692007000200019.

6. Manica J - Anestesiologia Princípios e Técnicas. 2a Ed, São Paulo, Artes Médicas, 1997; 288-293.

7. Rocha LCA. Retenção urinária aguda. Rev Assoc Med Bras 1990; 36(1): 26-8. APUD Fernandez.

8. Arone, Evanisa Maria. Enfermagem médico-cirúrgica aplicada ao sistema renal e urinário/elaboração de Evanisa Maria Arone, Maria Lúcia dos Santos Philippi - 2a ed. Rev. e ampl. - São Paulo: Editora Senac São Paulo, 2005.

9. Cervo, Amado Luis; Bervian,Pedro Alcino; Silva, Roberto. Metodologia Científica. 6.ed. São Paulo: Pearson Prentice hall, 2007.

10. Fachin, Odília. Fundamentos da metodologia. 5.ed. São Paulo: Saraiva, 2006. [11] Gil, Antônio Carlos. Como elaborar projetos de pesquisa. 5.ed. São Paulo: Atlas, 2010.

11. Gil, Antônio Carlos. Como elaborar projetos de pesquisa. 5.ed. São Paulo: Atlas, 2010

12. Mago, Adilson José Dal et al. Prevalência e fatores preditivos de retenção urinária diagnosticada por ultrassonografia no período pós-anestésico imediato. Rev. Bras. Anestesiol., Campinas, v. 60,n. 4, Agosto de 2010. Disponível em:<http://www.scielo.br/scielo. php?script=sci_arttext\&pid=S0034- 70942010000400005\&In $\mathrm{g}=\mathrm{en} \& \mathrm{nrm}=\mathrm{iso}>$. Acesso em 21 de Outubro de 2013.http:// dx.doi.org/10.1590/S0034-70942010000400005.

13. Jolley S. Intermittent catheterisation for post-operative urine retention. Nurs Times 1997; 93(33): 46-7.
14. Borges, Clóvis José da Silva; Araújo, Sávio José Romuando de. Betanecol no tratamento da retenção urinária provocada pela morfina subaracnóidea. Rev. Bras. Anestesiol., Campinas, v. 51, n. 4, 2001. Disponível em: <http://www.scielo.br/scielo. php?script=sci_arttext\&pid $=$ S0034- 70942001000400011\&ln $\mathrm{g}=\mathrm{en} \& \mathrm{nrm}=\mathrm{iso}>$. Acesso em: 13 de Abril 2014. http://dx.doi. org/10.1590/S0034-70942001000400011.

15. Rosseland LA, Stubhaug A, Breivik H - Detecting postoperative urinary retention with an ultrasound scanner. Acta Anaesthesiol Scand, 2002; 46: 279-282.

\section{Comment on this article:}
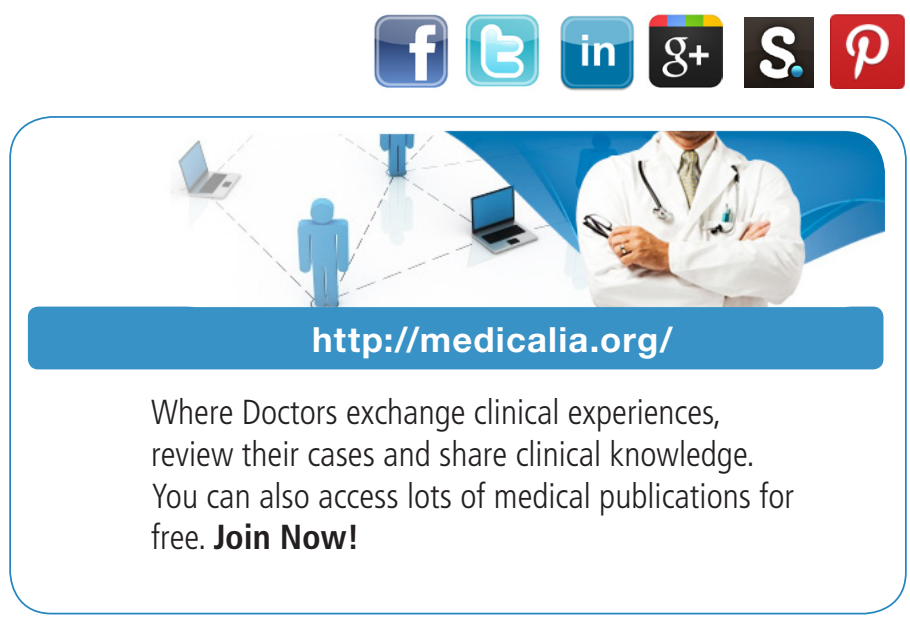

\section{Publish with iMedPub \\ http://www.imed.pub}

International Archives of Medicine is an open access journal publishing articles encompassing all aspects of medical science and clinical practice. IAM is considered a megajournal with independent sections on all areas of medicine. IAM is a really international journal with authors and board members from all around the world. The journal is widely indexed and classified Q1 in category Medicine. 